\title{
Relationship Between Undernutrition and Periodontal Diseases Among Yemen Population: a Cross-sectional Study
}

Milad Al-kalisi ( Milad.dent2020@yahoo.com )

Sana'a University Faculty of Dentistry

Manal Al-Hajri

Sana'a University Faculty of Dentistry

Sarah Al-Rai

Saba University

\section{Research article}

Keywords: Undernutrition, Gingivitis, Body mass index, Albumin

Posted Date: December 23rd, 2020

DOI: https://doi.org/10.21203/rs.3.rs-132860/v1

License: () (i) This work is licensed under a Creative Commons Attribution 4.0 International License. Read Full License 


\section{Abstract}

Background: Undernutrition is an inadequate supply of energy and nutrients. Periodontal diseases (PDs) defined as a broad form of chronic inflammatory diseases of the gingiva, bone and ligaments supporting the teeth. This study aimed to reveal the effect of undernutrition, using body mass index (BMI) and serum albumin level (Alb) on PDs and other risk factors as age, smoking and khat chewing.

Methods: This was a cross-sectional study conducted at the faculty of dentistry, Sana'a University. Of 1920 patients attended to clinics, only 229 matched the study criteria. Oral examination was performed to assess the periodontal clinical parameters measurements. BMI and Alb was measured. Statistical analysis was used to present the association between categorical variables was assessed using Chi square test and Fisher-Exact test. ANOVA was used to assess the differences in the mean values of the quantitative outcomes. Chi square test was used to evaluate the association between BMI and age, gender, occupation, education level, smoking, khat chewing as well as BMI with PDs.

Results: Most of participants (58.5\%) were males and most of the study sample (91.3\%) was at the age group of (18-35). Among all subjects, (81.2\%) of cases were diagnosed with gingivitis. (60.7\%) of study participants were mildly undernourished according to BMI. (93\%) of participants showed normal Alb level. Regarding to habits, only (18.2\%) of patients were smokers and more than half of participants (59.4\%) were khat chewers.

Conclusion: There was a relationship between PDs and undernutrition which was obviously seen between gingivitis and mild undernutrition.

\section{Background:}

Malnutrition is considered as a state of nutritional disorder that can be caused by a conjunction of inflammation and nutritional imbalance. The deficiency of energy, protein and other nutrients is called a negative nutrient balance that leads to undernutrition. While the excessive intake of food is called positive nutrient balance that leads to overnutrition. Malnutrition can cause an alteration in the body composition, function and clinical outcomes [1].

Periodontal diseases (PDs), including both gingivitis and periodontitis, are diseases induced by plaque and mainly affected by the immune and inflammatory reply causing breakdown of tissues enclosing and uploading the teeth [2]. PDs are caused by the imbalance between environmental factors, systemic conditions and host defense [3]. Moreover, the main cause of PDs is the poor oral hygiene that initiates disposition of dental plaque, comprising microorganisms, which increase the risk of periodontitis nearly two-to-five fold in contrast to good oral hygiene [4].

There are multiple risk factors that play important roles in an individual's response to periodontal infection [5-6]. These risk factors can be defined as enviromental, behavioral or biological factors. Moreover, the presence of these factors increases the rate of disease occurrence but not necessarily causing the disease. Risk factors are of two types: modifable and non-modifable. The common modifable factors are smoking [7-8], diabetes mellitus [9-13], microbiome [14-15], obesity [16-17], tobacco, betel nut chewing [18-19] and nutrition [20]. Whereas the non-modifiable factors may include genetic factors [21], ageing [22], gender [23-24] and socioeconomic status (SES) [25].

Although oral microorganisms are responsible for the pathogenesis of PDs [26-27], nutritional status can affect the balance between oral microorganism and the host response which is a trigger of PDs commencement and progression [27-29]. Undernutrition, specifically the protein-calorie, shows a reduction in immune host resistance specially the cellular immunity that causes an impairment in resistance to infection [30].

Body mass index (BMI) is the most commonly anthropometric method that is used as an indicator to assess the nutritional status in nutritional and epidemiological studies with or without other anthropometric methods to assess patients at nutritional risk [31]. Moreover, serum albumin level (Alb) can be used for identifying the inflammatory response and participating in the diagnosis of malnutrition [32].

The aims of this study were to provide a current evidence about the association between undernutrition and PDs and the relationship between undernutrition and other risk factors as age, smoking and khat chewing.

\section{Methods:}

\section{Study subjects:}

This cross-sectional study was conducted in Yemen, Sana'a. written informed consents were distributed to participants. Of 1290 patients who attended clinics of Oral Medicine, Oral Diagnosis and Periodontology department, faculty of dentistry, Sana'a University, Yemen, only 229 of patients matched the study criteria which includes undernourished patients with $\mathrm{BMI}<18.5$. Patients were collected randomly during the period from October 2018 to November 2019 . Patients with systemic diseases, pregnant and lactating women and patients older than 45 years were excluded.

\section{Baseline characteristics and data collection:}

This study was conducted in adherence to the Declaration of Helsinki. Ethical approval of the Human Ethics Committee of the medical faculty and health sciences of Sana'a University, Yemen was obtained. Sociodemographic data was collected through an interview including: age, gender, occupation, education level, teeth cleaning frequency, smoking and khat chewing. Oral examination was performed on the dental chair by using a sterile dental mirrors and Williams' probes by a single calibrated examiner (MA). Assessment of periodontal clinical parameters measurements were done including plaque index (PI), gingival index (GI), gingival recession (GR), probing pocket depth (PD) and clinical attachment loss (CAL). Kappa scores higher than 0.9 were attained for both interand intra-examiner calibration exercises for identifying periodontal clinical parameters. 
The undernourished patients' weights were measured in Kilograms by using a mechanical scale while participants wore light clothes and without shoes. Moreover, the height of the participants was measured in Centimeters by using a measuring tape while a hard ruler was positioned horizontally over the head of the participant to ensure a stable base. BMI was calculated by using the following formula: BMl=weight $(\mathrm{Kg}) / \mathrm{height}\left(\mathrm{m}^{2}\right)$. Blood samples were taken from each participant by a laboratory technician on the day of evaluation; samples were placed in special container then sent to the laboratory to measure Alb level. Standard Alb is from 3.5 to 5.5 gram per deciliter $(\mathrm{g} / \mathrm{dl})$.

\section{Statistical analysis:}

A power calculation was used to determine the minimum sample size required to establish significance. Sample size was calculated by using OpenEpi Info software, version 3, with confidence level 95\% and an estimated error 5\%. Data Analysis was undertaken using the Statistical Package for Social Science (SPSS version 16). Statistical analysis was used to present the demographic data of the study sample and diagnostic variables (IBM, Albumin level, and periodontal diseases) by frequencies and percentages. Association between categorical variables was assessed using Chi square test. Furthermore, Fisher Exact test was used when the assumptions of Chi square test couldn't not meet. Analysis of variance test (ANOVA) was used to assess the difference in the mean values of the quantitative outcomes (CAL). Chi square test was used to evaluate the association between $\mathrm{BMI}$ and age, gender, occupation, education level, smoking, khat chewing, as well as BMI with PDs. The significant level was set at $\mathrm{P}<0.05$. Figures (Bar charts) were used to present the descriptive data graphically.

\section{Results:}

Of 1920 patients who attended oral medicine, diagnosis and periodontology clinic, Sana'a University, only 229 patients matched with the study criteria.

Most of the sample (58.5\%) were males. Moreover, the majority of the sample (91.3\%) was at the age group of (18-35). Most of the participants (60.3\%) were students; furthermore, most of the sample's education level was bachelor degree (49.8\%). Only (18.2\%) of patients were smokers and more than half of the participants (59.4\%) were Khat chewers. demographic data of the study subject is shown in table (1).

The present study showed that most of cases had a mild undernutrition (60.7\%) and normal albumin level (93\%). Regarding the periodontal diagnosis, most of the patients were diagnosed with gingivitis (81.2\%), as shown in table (2).

In males group, age, level of education and smoking were significantly associated with $P D s(P=0.001, P=0.004, P=0.002$, respectively). Whereas, $B M I$, Albumin level and khat chewing were non-significant factors of $P D s(P=0.205, P=0.058, P=0.603$; respectively). While in females group, age, level of education, smoking and khat chewing were significantly associated with $P D s(P=0.014, P=0.000, P=0.002$, and $P=0.000$, respectively). In contrast, $B M I$ and albumin level were nonsignificantly associated with the PDs ( $\mathrm{P}=0.327, \mathrm{P}=1.000)$, as shown in table (3).

In both groups, variables such as age of the patients, smoking, khat chewing and PDs were non-significantly associated with BMI, as presented in table (4).

Mild malnutrition was the most frequent category in the patients diagnosed with gingivitis. On the other hand, mild malnutrition was the least frequent category in patients diagnosed with aggressive periodontitis, as shown in figure (1).

\section{Discussion:}

This study aimed to evaluate the association between PDs and undernutrition in Yemeni population and the correlation between undernutrition and other risk factors including age, gender, level of education and habits as smoking and khat chewing.

The results showed that there were non-statistically significant association between PDs and undernutrition participants. Mild undernutrition was found in $(60.7 \%)$ of study participants and gingivitis was diagnosed in (81.2\%) of study participants. This association may reveal that the reason of gingivitis presence in most of the study sample was the presence of mild undernutrition that may cause a little effect on the immune response.

$\mathrm{BMI}$ is the most common non-invasive tests to assess malnutrition [33]. Alb is also a well-known marker of nutritional status [34]. Low BMI and Alb in both genders were not significantly associated with PDs. The literature has reported that the severity of undernutrition has massive effects on the immune system which plays a role in progression of immunodeficiency [35]. There are many studies which clarified that the pathogenesis of periodontitis is significantly related to the host response with microbial factors [30,36-38]. The Cytokines, which are chemical mediators of inflammatory response, can be influenced by nutrition as a related factor [39]. People with severe undernutrition are more susceptible to many microbial opportunistic infections [40]. Therefore, this may clarify why low BMI and Alb is not significantly associated with PDs as most of the participants were in a mild undernutrition conditions.

Rodrigues et al., (2014) [41] published a positive correlation between hypoalbuminemia and periodontitis. A meta-analysis of 63 studies (2125 patients) discussed the effect of starvation on Alb and notified that the level of Alb remains normal before the patients reach the ultimate stage of starvation where undernutrition became physically evident [42]. In other words, hypoalbuminemia requires a more destructive inflammation and severe undernutrition to occur. Therefore, this may explain the non-significant relation between low BMI and Alb with PDs.

The present study showed that most of participants are between late adolescence and early adult and the majority of the samples were males (58.5\%) similar to Degarage et al., 2015 [43]. This can be explained by the neglect behavior and the inability of males to take care of themselves specially those who are studying away from their families and cannot cook food. Regarding the occupation, most of participants were students (60.3\%) and most of their education level was bachelor degree (49.8\%). Among males group, age, education level and smoking were significantly associated with $P D s(P=0.001, P=0.004, P=0.002$; respectively). There is a high prevalence of khat chewing in Yemen 43.27\% [44]. Khat chewing habits promote the development of other habits like cigarette 
smoking [45-46]. smoking is considered as one of the most or significant life style factors that is associated or linked to PDs. It is considered as a detrimental factor that influence the occurrence and progression of periodontitis [47-48]. This can be explained by the Yemeni society lifestyle of chewing khat which is a common practice among high schools, colleges and university students, since it is considered as a mild stimulant that promote energy during working or studying [49]. Most chewers get a good degree of concentration and raise energy levels and awareness, promote imaginative ability and capacity to incorporate ideas, and enhance the ability to communicate especially among Yemeni males [50]. khat chewing caused obvious CNS symptoms such as loss of appetite (anorexia) and may be associated with the mixed effect of the central amphetamine-like with delaying of gastric empty and insomnia that leads to late waking up in the morning and a reduced activity performance caused by the central release of noradrenergic neurotransmitters [51-52]. Moreover, cathinone promotes or elevates the sympathomimetic activity that results in a late discharge of food from stomach [53]. This may explain why khat chewing can lead to malnutrition.

Poor oral hygiene among males is another risk factor of gingivitis. This can be due to the masculinity behavior of thinking that oral hygiene is not connected to men strength [54]. In contrast, chronic periodontitis presented in the older age [55] and persons of age 40 and above were four times more probably to have periodontitis than younger ages [56]. This may explain why the majority of the sample was diagnosed with gingivitis.

Among females group; age, level of education, smoking and khat chewing were significantly associated with the $P D s(P=0.014, P=0.000, P=0.002, P=0.000$; respectively) due to the previous reasons that explained in males group.

Limitation was the lack of knowledge of patient about the importance of BMI and Alb in diagnosing undernutrition which was an obstacle during conducting sample.

\section{Conclusions:}

In conclusion, the relationship between PDs and undernutrition was proven between gingivitis and mild undernutrition. There was a slight relationship between periodontitis and mild undernutrition. Khat chewing habit showed to be the most probable cause of undernutrition in Yemen.

\section{Abbreviation:}

PDs: periodontal diseases; BMI: body mass index; Alb: albumin serum level; Pl: plaque index; Gl: gingival index; GR: gingival recession; PD: pocket depth; CAL: clinical attachment loss

\section{Declarations:}

\section{Acknowledgment}

Not Applicable

\section{Author's contribution}

MA and MA conceived and designed the study, analyzed the data and drafted the manuscript. SA contributed to drafting the manuscript. All authors have read, reviewed and approved the manuscript.

\section{Funding}

There was no fund

\section{Availability of data and materials}

The datasets generated during and/or analyzed during the current study are not publicly available due to ethical reasons, but are available from the corresponding author on reasonable request.

\section{Ethics approval and consent to participate}

This study was approved by Ethical approval of the Human Ethics Committee of the medical faculty and health sciences of Sana'a University, Yemen was obtained. All subjects in this study provided written informed consent to participate.

\section{Consent for publication}

Not applicable.

\section{Competing interests}

The authors declare no competing interests.

\section{References:}

1. Soeters P, Bozzetti F,Cynober L, Elia M, Shenkin A, Sobotka L. Meta-analysis is not enough: the critical role of pathophysiology in determining optimal care in clinical nutrition. Clin Nutr. 2016; 35:748-57. 
2. Madiba T, Bhayat A. Periodontal disease-risk factors and treatment options. S Afr Dent J. 2018;73: 571-75.

3. Amaliya A. Java Project on Periodontal Disease: Periodontal Condition in Relation to Vitamin C, Systemic Conditions and Tooth Loss, Universiteit van Amsterdam.2014.

4. Lertpimonchai A, Rattanasiri S, Arj-Ong Vallibhakara S, Attia J, Thakkinstian A.The association between oral hygiene and periodontitis: a systematic review and meta-analysis. Int Dent J. 2017;67:332-43.

5. Khan F, Aziz A, Shahab S, Zafar M. Laboratorial and clinical impacts of tobacco on periodontal health: A systematic review.Int Dent J Stud Res.2015;3: 7278.

6. Genco R, Borgnakke W. Risk factors for periodontal disease. Periodontol 2000. 2013; 62: 59-94.

7. Vouros I, Kalpidis C, Chadjipantelis T, Konstantinidis A. Cigarette smoking associated with advanced periodontal destruction in a Greek sample population of patients with periodontal disease. Jnt Acad Periodontol. 2009;11: 250-57.

8. Kubota M, Tanno-Nakanishi M, Yamada S, Okuda K, Ishihara K. Effect of smoking on subgingival microflora of patients with periodontitis in Japan.BMC Oral Health. 2011; 11:1.

9. Campus G, Salem A, Uzzau S, Baldoni E,Tonolo G. Diabetes and periodontal disease: A case-control study. J Periodontol. 2005;76: 418-25.

10. Stegeman C. Oral manifestations of diabetes. Home Health Nurse. 2005; 23: 233-40; quiz 241-232.

11. Graves D, Liu R, Alikhani M, Al-Mashat H, Trackman P. Diabetes-enhanced inflammation and apoptosis-impact on periodontal pathology. J Dent Res. 2006;85: 15-21.

12. Meng H. Association between periodontitis and diabetes mellitus. Beijing da xue xue bao Yi xue ban/ Journal of Peking University. Health sciences. 2007;39: 18-20.

13. Nishimura F, Iwamoto Y, Soga Y.The periodontal host response with diabetes. Periodontol 2000. 2007;43: 245-53.

14. Paster B, Olsen I, Aas J, Dewhirst F. The breadth of bacterial diversity in the human periodontal pocket and other oral sites. Periodontol 2000. 2006;42: 8087.

15. Berezow A, Darveau R. Microbial shift and periodontitis. Periodontol 2000. 2011;55: 36.

16. Chaffee B, Weston S. Association between chronic periodontal disease and obesity: a systematic review and meta-analysis. J Periodontol. 2010;81: 170824.

17. Suvan J, Petrie A, Moles D, Nibali L, Patel K, Darbar U, Donos N, Tonetti M, Aiuto F. Body mass index as a predictive factor of periodontal therapy outcomes. J Dent Res. 2014; 93: 49-54.

18. Chang Y, Lii C, Tai K, Chou M. Adverse effects of arecoline and nicotine on human periodontal ligament fibroblasts in vitro.J Clin Periodontol. 2001;28(3): 277-82.

19. Fiorini T, Musskopf M, Oppermann R, Susin C. Is there a positive effect of smoking cessation on periodontal health? A systematic review. J Periodontol. 2014;85: 83-91.

20. Mehta A. Risk factors associated with periodontal diseases and their clinical considerations. Int J Contemp Dent Med Rev. 2015: 1-5.

21. Van Dyke TE, Dave S. Risk factors for periodontitis. J Int Acad Periodontol .2005;7: 3-7.

22. Al Habashneh R, Alchalabi H, Khader Y, Hazza'a A, Odat Z, Johnson G. Association between periodontal disease and osteoporosis in postmenopausal women in Jordan. J Periodontol. 2010;81: 1613-21.

23. Mundt T, Schwahn C, Mack F, Polzer I, Samietz S, Kocher T, Biffar R. Risk indicators for missing teeth in working-age Pomeranians-an evaluation of highrisk populations. Public Health Dent.2007;67: 243-49.

24. Meisel P, Reifenberger J, Haase R, Nauck M, Bandt C, Kocher T. Women are periodontally healthier than men, but why don't they have more teeth than men?. Menopause. 2008;15: 270-75.

25. Gilbert G. Racial and socioeconomic disparities in health from population-based research to practice-based research: the example of oral health.J Dent Edu. 2005;69:1003-14.

26. Alagl A, Bhat S. Ascorbic acid: New role of an age-old micronutrient in the management of periodontal disease in older adults. Geriatr Gerontol Int Title. 2015;15: 241-54.

27. Varela-López A, Navarro-Hortal M, Giampieri F, Bullón P, Battino M, Quiles J. Nutraceuticals in periodontal health: a systematic review on the role of vitamins in periodontal health maintenance.Molecules.2018;23: 1226.

28. Massaro M, Scoditti E, Carluccio M, De Caterina R. Nutraceuticals and prevention of atherosclerosis: focus on $\omega-3$ polyunsaturated fatty acids and mediterranean diet polyphenols. CARDIOVASC THER. 2010;28: e13-e19.

29. Chauhan B, Kumar G, Kalam N, Ansari S. Current concepts and prospects of herbal nutraceutical: a review. Adv. Pharm. Technol. 2013; 4: 4-8.

30. Chandra, R. Effect of post-natal protein malnutrition and intrauterine growth retardation on immunity and risk of infection. Nutrition and immune function. 2002; 41-56.

31. Barao K, Forones N. Body mass index: different nutritional status according to WHO, OPAS and Lipschitz classification in gastrointestinal cancer patients. Arq Gastroenterol. 2012; 49: 169-71.

32. Blanck H, Bowman B, Cooper G, Myers G, Miller D. Laboratory issues: Use of nutritional biomarkers. J Nutr. 2003;133:888S-894S.

33. Howard R, Thai V, Patton P, Hemming A, Reed A, Van Der Werf W, Fujita S, Karlix J, Scornik J. Obesity does not portend a bad outcome for kidney transplant recipients. Transplantation. 2002; 73: 53-55. 
34. Kuzuya M, Izawa S, Enoki H,Okada K, Iguchi A. Is serum albumin a good marker for malnutrition in the physically impaired elderly?. Clin Nutr. 2007;26:8490.

35. Geraix J. Efeito da fibra solúvel sobre a hipertrigliceridemia e perfil imunológico de indivíduos HIV positivo em uso de terapia anti-retroviral de alta atividade.2008.

36. Słotwińska S, Słotwiński R. Host response, malnutrition and oral diseases. Part 2. Cent Eur J Immunol. 2014;9: 522-24.

37. Van Dyke T, Serhan C. Resolution of inflammation: a new paradigm for the pathogenesis of periodontal diseases.J Dent Res.2003;82:82-90.

38. Grimble R. Modification of inflammatory aspects ofimmune function by nutrients. Nutr Res. 1998; 18: 1297-1317.

39. Grimble R. Dietary manipulation of the inflammatory response. Proc Nutr Soc. 1992;51(2):285-94.

40. Aaby P. Is susceptibility to severe infection in low-income countries inherited or acquired?. J Intern Med. 2007;261:112-22.

41. Rodrigues V, Liberio S, Lopes F, Thomaz E, Guerra R, Gomes-Filho I, Pereira A. Periodontal status and serum biomarkers levels in haemodialysis patients. J Clin Periodontol. 2014;41:862-68.

42. Lee J, Oh E, Lee R, Finucane T. Serum Albumin and Prealbumin in Calorically Restricted, Nondiseased Individuals: A Systematic Review. Am J Med. 2015;128: 1023 e1021-22.

43. Degarege D, Degarege A, Animut A. Undernutrition and associated risk factors among school age children in Addis Ababa, Ethiopia. BMC Public Health;2015.15: 375.

44. Ayano G., Yohannis K, Abraha M. Epidemiology of khat (Catha edulis) consumption among university students: a meta-analysis. BMC public health.2019;19: 150.

45. Gashawa A, Getachew T. The chemistry of khat and adverse effect of khat chewing.ASRJETS. 2014; 9: 35-46.

46. Nakajima M, al'Absi M, Dokam A, Alsoofi M, Khalil N, Al Habori M. Gender differences in patterns and correlates of khat and tobacco use. Nicotine Tob. Res. 2013;15: 1130-35.

47. Bergström J. Tobacco smoking and chronic destructive periodontal disease. Odontology. 2004;92: 1-8.

48. Leite F, Nascimento G, Scheutz F, Lopez R. Effect of smoking on periodontitis: a systematic review and meta-regression. Am J Prev Med. $2018 ; 54:$ 831-41.

49. Ageely H. Health and socio-economic hazards associated with khat consumption. J Family Community Med. 2008;15: 3-11.

50. Basker G. A review on hazards of khat chewing. Int J Pharm Pharm Sci. 2013;5:74-77.

51. Hassan N, Gunaid A, El-Khally F, Murray-Lyon I. The effect of chewing Khat leaves on human mood. Saudi Med J. 2002;23:850-853.

52. Murray C, Le Roux C, Emmanuel A, Halket J, Przyborowska A, Kamm M, Murray-Lyon I.The effect of khat (Catha edulis) as an appetite suppressant is independent of ghrelin and PYY secretion. Appetite. 2008;51(3): 747-50.

53. Tucci S. Phytochemicals in the Control of Human Appetite and Body Weight. Pharmaceuticals (Basel). 2010; 3:748-63.

54. Vaidya P, Jindal V, Tuli A, Gautam D, Gupta S. Aggressive Periodontitis-As A Clinical Entity. Indian J Dent Sci. 2012;4(1).

55. Tadjoedin F, Fitri A, Kuswandani S, Sulijaya B, Soeroso Y. The correlation between age and periodontal diseases. Int. Dent. Medical Res.2017;10(2): 32732.

56. Bokhari S, Suhail A, Malik A, Imran M. Periodontal disease status and associated risk factors in patients attending a Dental Teaching Hospital in Rawalpindi, Pakistan. Indian Soc. Periodontol. 2015;19: 678.

\section{Tables:}


Table 1

Sociodemographic characteristics of the study sample.

\begin{tabular}{|c|c|c|c|}
\hline \multicolumn{2}{|l|}{ Variables } & \multirow{2}{*}{$\begin{array}{l}\text { Frequency } \\
209\end{array}$} & \multirow{2}{*}{$\begin{array}{l}\% \\
91.3 \%\end{array}$} \\
\hline Age & $18-35$ & & \\
\hline & $35-50$ & 20 & $8.7 \%$ \\
\hline \multirow[t]{2}{*}{ Gender } & Male & 134 & $58.5 \%$ \\
\hline & Female & 95 & $41.5 \%$ \\
\hline \multirow[t]{11}{*}{ Occupation } & Student & 138 & $60.3 \%$ \\
\hline & House wife & 32 & $14.0 \%$ \\
\hline & Retired & 0 & $0.0 \%$ \\
\hline & Farmer & 0 & $0.0 \%$ \\
\hline & Teacher & 1 & $0.4 \%$ \\
\hline & Doctor & 0 & $0.0 \%$ \\
\hline & Merchant & 0 & $0.0 \%$ \\
\hline & Livestock breeder & 0 & $0.0 \%$ \\
\hline & Craftsman & 2 & $0.9 \%$ \\
\hline & Others & 41 & $17.9 \%$ \\
\hline & Cannot find a job & 15 & $6.6 \%$ \\
\hline \multirow[t]{6}{*}{ Education Level } & Not educated & 45 & $19.7 \%$ \\
\hline & Elementary & 13 & $5.7 \%$ \\
\hline & Secondary & 50 & $21.8 \%$ \\
\hline & Diploma & 7 & $3.1 \%$ \\
\hline & Bachelor & 114 & $49.8 \%$ \\
\hline & Master & 0 & $0.0 \%$ \\
\hline \multirow[t]{2}{*}{ Smoking } & No & 186 & $81.2 \%$ \\
\hline & Yes & 43 & $18.8 \%$ \\
\hline \multirow[t]{2}{*}{ Khat Chewing } & No & 93 & $40.6 \%$ \\
\hline & Yes & 136 & $59.4 \%$ \\
\hline
\end{tabular}

Table 2

$\mathrm{BMI}$, Albumin level, and periodontal diagnosis characteristics of the study sample.

\begin{tabular}{|llll|}
\hline Variables & & Frequency & $\%$ \\
\hline BMI & Mild & 139 & $60.7 \%$ \\
\cline { 2 - 4 } & Moderate & 59 & $25.8 \%$ \\
\cline { 2 - 4 } Albumin level & Sever & 31 & $13.5 \%$ \\
\cline { 2 - 4 } & Normal & 213 & $93.0 \%$ \\
\cline { 2 - 4 } Diagnosis & Low & 16 & $7.0 \%$ \\
& Healthy & 9 & $3.9 \%$ \\
& Gingivitis & 186 & $81.2 \%$ \\
\cline { 2 - 4 } & Chronic periodontitis & 32 & $14.0 \%$ \\
\cline { 2 - 4 } & Aggressive periodontitis & 2 & $0.9 \%$ \\
\hline
\end{tabular}

Page $7 / 10$ 
Table 3

The correlation of study variables with PDs in males and females groups

\begin{tabular}{|c|c|c|c|c|c|c|c|c|c|c|c|c|c|c|c|c|c|c|}
\hline \multirow[t]{5}{*}{ Variables } & & \multicolumn{17}{|c|}{ Gender } \\
\hline & & \multicolumn{8}{|c|}{ Males } & \multicolumn{9}{|c|}{ Females } \\
\hline & & \multicolumn{17}{|c|}{ Diagnosis } \\
\hline & & \multicolumn{2}{|c|}{$\begin{array}{l}\text { Healthy } \\
n=(0)\end{array}$} & \multicolumn{2}{|c|}{$\begin{array}{l}\text { Gingivitis } \\
\mathrm{n}=(111)\end{array}$} & \multicolumn{2}{|c|}{$\begin{array}{l}\text { Chronic } \\
\text { periodontitis } \\
\mathrm{n}=(21)\end{array}$} & \multicolumn{2}{|c|}{$\begin{array}{l}\text { Aggressive } \\
\text { periodontitis } \\
n=(2)\end{array}$} & & \multicolumn{2}{|c|}{$\begin{array}{l}\text { Healthy } \\
n=(9)\end{array}$} & \multicolumn{2}{|c|}{$\begin{array}{l}\text { Gingivitis } \\
(n=75)\end{array}$} & \multicolumn{2}{|c|}{$\begin{array}{l}\text { Chronic } \\
\text { periodontitis } \\
(n=11)\end{array}$} & \multicolumn{2}{|c|}{$\begin{array}{l}\text { Aggressive } \\
\text { periodontitis } \\
(n=0)\end{array}$} \\
\hline & & $\mathrm{F}$ & $\%$ & $\mathrm{~F}$ & $\%$ & $\mathrm{~F}$ & $\%$ & $\mathrm{~F}$ & $\%$ & $\begin{array}{l}\mathrm{P}- \\
\text { value }\end{array}$ & $\mathrm{F}$ & $\%$ & $\mathrm{~F}$ & $\%$ & $\mathrm{~F}$ & $\%$ & $\mathrm{~F}$ & $\%$ \\
\hline \multirow[t]{2}{*}{ Age } & $18-35$ & 0 & $0.0 \%$ & 106 & 95.50 & 15 & 71.43 & 1 & 50.0 & \multirow[t]{2}{*}{$.001^{*}$} & 9 & 100.0 & 71 & 94.7 & 7 & 63.6 & 0 & $0.0 \%$ \\
\hline & $35-50$ & 0 & $0.0 \%$ & 5 & $41.7 \%$ & 6 & 52.38 & 1 & 100.0 & & 0 & 55.6 & 4 & 5.3 & 4 & 36.4 & 0 & $0.0 \%$ \\
\hline \multirow[t]{6}{*}{$\begin{array}{l}\text { Education } \\
\text { Level }\end{array}$} & $\begin{array}{l}\text { Not } \\
\text { educated }\end{array}$ & 0 & $0.0 \%$ & 17 & 15.32 & 9 & 42.86 & 0 & 0.0 & \multirow[t]{6}{*}{$.004^{\star}$} & 1 & 11.1 & 9 & 12.0 & 9 & 81.8 & 0 & $0.0 \%$ \\
\hline & Elementary & 0 & $0.0 \%$ & 2 & 1.80 & 2 & 9.52 & 0 & 0.0 & & 0 & 0.0 & 8 & 10.7 & 1 & 9.1 & 0 & $0.0 \%$ \\
\hline & Secondary & 0 & $0.0 \%$ & 25 & 22.52 & 4 & 19.05 & 0 & 0.0 & & 1 & 11.1 & 20 & 26.7 & 0 & 0.0 & 0 & $0.0 \%$ \\
\hline & Diploma & 0 & $0.0 \%$ & 3 & 2.70 & 0 & 0.00 & 1 & 50.0 & & 0 & 0.0 & 3 & 4.0 & 0 & 0.0 & 0 & $0.0 \%$ \\
\hline & Bachelor & 0 & $0.0 \%$ & 64 & 57.66 & 6 & 28.57 & 1 & 50.0 & & 7 & 77.8 & 35 & 46.7 & 1 & 9.1 & 0 & $0.0 \%$ \\
\hline & Master & 0 & $0.0 \%$ & 0 & 0.00 & 0 & 0.00 & 0 & 0.0 & & 0 & 0.0 & 0 & 0.0 & 0 & 0.0 & 0 & $0.0 \%$ \\
\hline \multirow[t]{2}{*}{ Smoking } & No & 0 & $0.0 \%$ & 94 & 84.68 & 11 & 52.38 & 1 & 50.0 & \multirow[t]{2}{*}{$.002^{*}$} & 9 & 100.0 & 66 & 88.0 & 5 & 45.5 & 0 & $0.0 \%$ \\
\hline & Yes & 0 & $0.0 \%$ & 17 & 15.32 & 10 & 47.62 & 1 & 50.0 & & 0 & 0.0 & 9 & 12.0 & 6 & 54.5 & 0 & $0.0 \%$ \\
\hline \multirow{2}{*}{$\begin{array}{l}\text { Khat } \\
\text { Chewing }\end{array}$} & No & 0 & $0.0 \%$ & 21 & 18.92 & 6 & 28.57 & 0 & 0.0 & \multirow[t]{2}{*}{.603} & 9 & 100.0 & 55 & 73.3 & 2 & 18.2 & 0 & $0.0 \%$ \\
\hline & Yes & 0 & $0.0 \%$ & 90 & 81.08 & 15 & 71.43 & 2 & 100.0 & & 0 & 0.0 & 20 & 26.7 & 9 & 81.8 & 0 & $0.0 \%$ \\
\hline \multirow{2}{*}{$\begin{array}{l}\text { Albumin } \\
\text { Level }\end{array}$} & Normal & 0 & $0.0 \%$ & 106 & 95.50 & 19 & 90.48 & 1 & 50.0 & \multirow[t]{2}{*}{.058} & 9 & 100.0 & 68 & 90.7 & 10 & 90.9 & 0 & $0.0 \%$ \\
\hline & Low & 0 & $0.0 \%$ & 5 & 4.50 & 2 & 9.52 & 1 & 50.0 & & 0 & 0.0 & 7 & 9.3 & 1 & 9.1 & 0 & $0.0 \%$ \\
\hline \multirow[t]{3}{*}{ BMI } & Mild & 0 & $0.0 \%$ & 74 & 66.67 & 11 & 52.38 & 2 & 100.0 & .205 & 5 & 55.6 & 43 & 57.3 & 4 & 36.4 & 0 & $0.0 \%$ \\
\hline & Moderate & 0 & $0.0 \%$ & 26 & 23.42 & 4 & 19.05 & 0 & 0.0 & & 3 & 33.3 & 23 & 30.7 & 3 & 27.3 & 0 & $0.0 \%$ \\
\hline & Severe & 0 & $0.0 \%$ & 11 & 9.91 & 6 & 28.57 & 0 & 0.0 & & 1 & 11.1 & 9 & 12.0 & 4 & 36.4 & 0 & $0.0 \%$ \\
\hline
\end{tabular}


Table 4

The correlation between BMI with age, smoking, khat chewing and PDs among males and females.

\begin{tabular}{|c|c|c|c|c|c|c|c|c|c|}
\hline \multirow[t]{3}{*}{ Variables } & & & \multicolumn{6}{|c|}{ BMI } & \multirow[t]{3}{*}{ P-value } \\
\hline & & & \multicolumn{2}{|c|}{ Mild } & \multicolumn{2}{|c|}{ Moderate } & \multicolumn{2}{|c|}{ Severe } & \\
\hline & & & $\mathrm{N}$ & $\%$ & $\mathrm{~N}$ & $\%$ & $\mathrm{~N}$ & $\%$ & \\
\hline \multirow[t]{10}{*}{ Male } & \multirow[t]{2}{*}{ Age } & $18-35$ & 79 & $90.8 \%$ & 28 & $93.3 \%$ & 15 & $88.2 \%$ & \multirow[t]{2}{*}{0.814} \\
\hline & & $35-50$ & 8 & $9.2 \%$ & 2 & $6.7 \%$ & 2 & $11.8 \%$ & \\
\hline & \multirow[t]{2}{*}{ Smoking } & No & 71 & $81.6 \%$ & 24 & $80.0 \%$ & 11 & $64.7 \%$ & \multirow[t]{2}{*}{0.303} \\
\hline & & Yes & 16 & $18.4 \%$ & 6 & $20.0 \%$ & 6 & $35.3 \%$ & \\
\hline & \multirow[t]{2}{*}{ khat Chewing } & No & 19 & $21.8 \%$ & 5 & $16.7 \%$ & 3 & $17.6 \%$ & \multirow[t]{2}{*}{0.855} \\
\hline & & Yes & 68 & $78.2 \%$ & 25 & $83.3 \%$ & 14 & $82.4 \%$ & \\
\hline & \multirow[t]{4}{*}{ Diagnosis } & Healthy & 0 & $0.0 \%$ & 0 & $0.0 \%$ & 0 & $0.0 \%$ & \multirow[t]{4}{*}{0.205} \\
\hline & & Gingivitis & 74 & $85.1 \%$ & 26 & $86.7 \%$ & 11 & $64.7 \%$ & \\
\hline & & Chronic Periodontitis & 11 & $12.6 \%$ & 4 & $13.3 \%$ & 6 & $35.3 \%$ & \\
\hline & & Aggressive Periodontitis & 2 & $2.3 \%$ & 0 & $0.0 \%$ & 0 & $0.0 \%$ & \\
\hline \multirow[t]{10}{*}{ Female } & \multirow[t]{2}{*}{ Age } & $18-35$ & 50 & $96.2 \%$ & 26 & $89.7 \%$ & 11 & $78.6 \%$ & \multirow[t]{2}{*}{0.062} \\
\hline & & $35-50$ & 2 & $3.8 \%$ & 3 & $10.3 \%$ & 3 & $21.4 \%$ & \\
\hline & \multirow[t]{2}{*}{ Smoking } & No & 44 & $84.6 \%$ & 25 & $86.2 \%$ & 11 & $78.6 \%$ & \multirow[t]{2}{*}{0.854} \\
\hline & & Yes & 8 & $15.4 \%$ & 4 & $13.8 \%$ & 3 & $21.4 \%$ & \\
\hline & \multirow[t]{2}{*}{ khat Chewing } & No & 36 & $69.2 \%$ & 21 & $72.4 \%$ & 9 & $64.3 \%$ & \multirow[t]{2}{*}{0.824} \\
\hline & & Yes & 16 & $30.8 \%$ & 8 & $27.6 \%$ & 5 & $35.7 \%$ & \\
\hline & \multirow[t]{4}{*}{ Diagnosis } & Healthy & 5 & $9.6 \%$ & 3 & $10.3 \%$ & 1 & $7.1 \%$ & \multirow[t]{4}{*}{0.327} \\
\hline & & Gingivitis & 43 & $82.7 \%$ & 23 & $79.3 \%$ & 9 & $64.3 \%$ & \\
\hline & & Chronic Periodontitis & 4 & $7.7 \%$ & 3 & $10.3 \%$ & 4 & $28.6 \%$ & \\
\hline & & Aggressive Periodontitis & 0 & $0.0 \%$ & 0 & $0.0 \%$ & 0 & $0.0 \%$ & \\
\hline
\end{tabular}

\section{Figures}

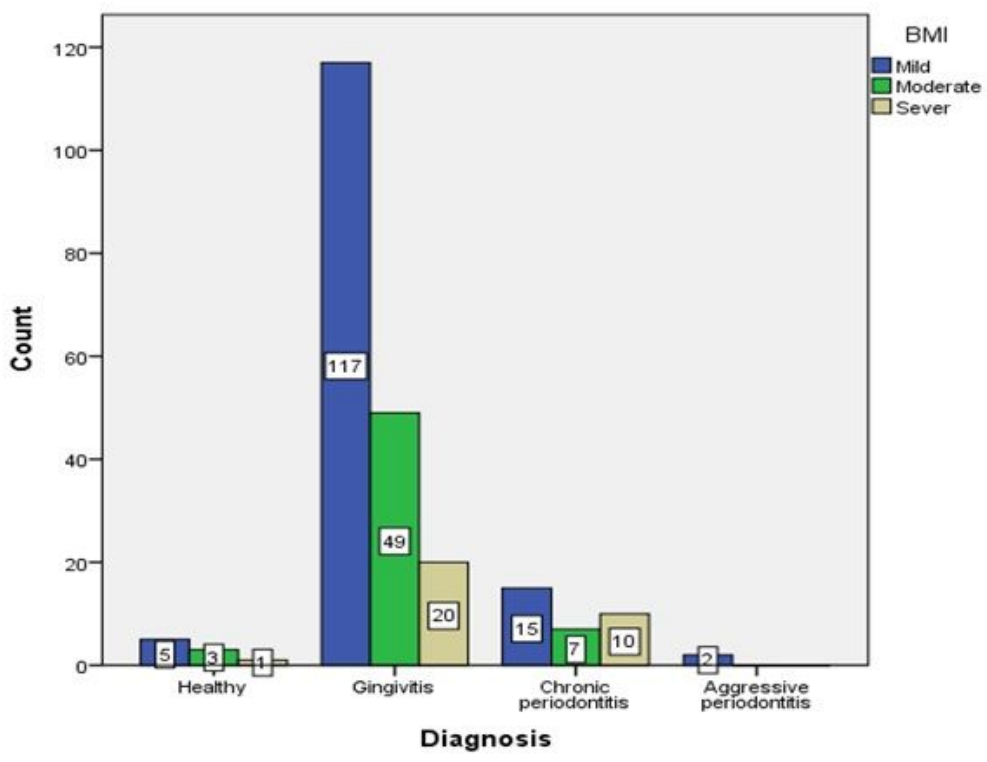

Figure 1 
Distribution of undernutrition patients with periodontal disease.

Page $10 / 10$ 